\title{
The Alleged Anonymity of the Canonical Gospels
}

\begin{abstract}
The apparent anonymity of the Gospels is a neglected topic in NT studies. The present article offers an investigation of it. It will survey the work that has been done specifically on the subject, as well as how it is treated in Gospels scholarship more broadly. The main body of the argument is in two parts. First, anonymity cannot be defined by the lack of reference to a name in the body of the work, and therefore the argument that the Gospels are anonymous because they do not contain the authors' names is invalid. Secondly, and more positively, while the titles contained in the earliest Gospel manuscripts may well in their present form be secondary, this does not exclude attributions of authorship made in some other way. Aspects of practical necessity make the presence of author's names very likely. Second-century Christian literature is replete with references to Matthew, Mark, Luke and John as authors of Gospels, and there is never any sense that the Gospels were anonymous or written by others. The most likely conclusion to be drawn is that the attributions of authorship are original.
\end{abstract}

It has been said by Terry Eagleton that 'all literary works are anonymous, but some are more anonymous than others. ${ }^{11}$ The canonical Gospels are usually classed very much on the 'more anonymous' side, but surprisingly this apparent anonymity of the Gospels has received relatively short shrift. What little discussion there has been has taken place mainly in Germany, and among those discussions treatment of anonymity has often been lumped in with its bigger sister, pseudonymity. As David Aune has noted, the topic of the anonymity of biblical books 'has been almost completely neglected'. ${ }^{2}$

This article will begin $(\S 1)$ with a brief review of scholarship on the subject over the past half-century, both in specialised studies and more broadly. From this it can be clearly seen that the great majority of scholars, including leading figures in current Gospels research such as Michael Wolter and Francis Watson, hold to a view of the Gospels as anonymous. It is the intention of the present article to take issue with this position. The argument against the majority proceeds with negative and positive arguments. The negative argument (\$2) consists in an assessment of the significance of there being no author mentioned within the body of the work, concluding that it is of no significance at all as evidence for anonymity. The more constructive argument

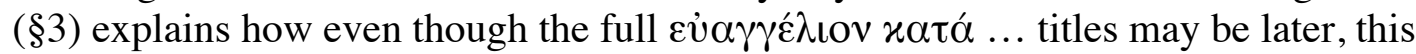
does not permit the conclusion of anonymity because there is considerable positive evidence for the antiquity, even the originality, of the names. The aim of the article is hence to show that the standard reasons for considering the Gospels anonymous cannot support the claim that they are, and to contend instead that the most likely conclusion from the evidence is that the attributions go back to the first century. The

\footnotetext{
${ }^{1}$ T. Eagleton, 'Unhoused', London Review of Books 30.10 (22 May 2008), p. 19.

${ }^{2}$ D.E. Aune, 'Anonymity', in idem (ed.), The Westminster Dictionary of New Testament and Early Christian Literature and Rhetoric (Louisville: WJK, 2003), p. 35. I owe this reference to the article of Baum discussed further below.
} 
aim here is not to say that Matthew, Mark, Luke and John wrote the Gospels, still less to argue for a fourfold Gospel canon. Nor is the argument concerned with the form or

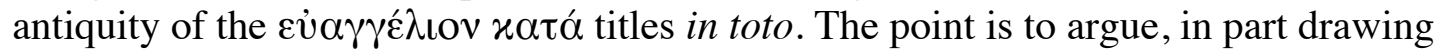
on evidence already adduced by others, but with new arguments and new testimonia, that as far back as we can go, and probably from the beginning, these were the names attached to the Gospels.

\section{The Anonymity of the Gospels in Current Gospels Scholarship}

\subsection{Specialised Studies}

One of the most important articles to spark off interest in the subject is that of Kurt Aland, in an essay covering both anonymity and pseudonymity. ${ }^{3}$ Aland takes it as read that these two topics need to be considered together (p. 40). He includes in the category of the 'anonymous writings' of the New Testament Hebrews, 1 John and the Gospels (p. 41): 'In my opinion it is beyond doubt that all the gospels were published anonymously. Our present opinion about their authors dates from information which derives from the time of Papias or later' (p. 42). As one might expect from Aland, he makes reference here to some of the manuscript evidence. The reason he offers for the anonymity of the Gospel writers lies in the fact that the authors regard themselves as mere quills of the Holy Spirit. When Luke wrote, for example, his Gospel 'just passed through him as a person... He was but the pen moved by the Spirit.' We would need an explanation if the author had provided his name (p. 45). The written Gospels, Aland avers, are simply the transposition of spirit-inspired oral discourse into writing. The shift towards named authors (like Justin) of Christian works takes place in the second century, when prophetic inspiration (along with expectation of the parousia) wanes (p. 47).

A second article by Aland repeats many of the concerns of the former piece. ${ }^{5}$ These include the needs to treat the two topics together, to take a broader view encompassing Christian literature of the first two centuries, and to treat Christian literature as distinctive - not out of a Christian exceptionalism, but because of the special factors of the prophetic spirit and the delay of the parousia which Aland sees as having a particular impact on authorship. Aland begins by noting that anonymity has attracted much less attention than pseudonymity (p. 122). Overall, not a great deal is added for our purposes: only one paragraph deals with the anonymous literature of the NT, and that is taken up with the epistle to the Hebrews.

\footnotetext{
${ }^{3}$ K. Aland, 'The Problem of Anonymity and Pseudonymity in Christian Literature of the First Two Centuries', JTS 12 (1961), pp. 39-49, reprinted in idem, The Authority and Integrity of the New Testament (London: SPCK, 1965), pp. 1-13. German version: 'Das Problem der Anonymität und Pseudonymität in der christlichen Literatur der ersten beiden Jahrhunderte', in idem, Studien zur Überlieferung des Neuen Testaments und seines Textes (Berlin/ New York: De Gruyter, 1967), pp. 2434. Page references in the text above are from the JTS publication.

${ }^{4}$ Aland considers it unclear, however, whether John's Gospel is really anonymous or pseudonymous (p. 41).

${ }^{5}$ K. Aland, 'Noch einmal: Das Problem der Anonymität und Pseudonymität in der christlichen Literatur der ersten beiden Jahrhunderte', in E. Dassmann \& K.S. Frank (eds.), Pietas: Festschrift für Bernhard Kötting (Münster: Aschendorff, 1980), pp. 121-139.
} 
Partly in response to Aland's former piece, an article by Horst Balz also provides a treatment of the two topics. ${ }^{6}$ Balz also considers that they ought to be treated together because 'Pseudepigraphie ist ... als Extremfall der Anonymität zu werten' (p. 434; cf. 406). The article is more wide-ranging than Aland's focus on Christian literature of the first two centuries, but on the other hand, the article is taken up with pseudonymity to a much greater extent than with anonymity. In the eight-page treatment of the pagan context only the last sentence really discusses anonymity, although Balz does cover instances where originally anonymous material becomes pseudepigraphic, such as the works attributed to Homer and Aesop (pp. 408-416). These examples in his view provide an analogy or a background to what happened with the Gospels (p. 417). When it comes to explaining anonymity in early Christian literature, Balz, in contrast to Aland, focuses not so much on the inspired process of composition, but on the fact the author is only passing on traditional material, and so can - indeed must - remain anonymous (pp. 433-434). The discussion of the Gospels runs to just over one page, and stresses that the authors are focused simply on reworking tradition, with their products entirely marked in Balz's view by their function of presenting in a stable form the gospel as it was preached in their particular communities (pp. 428-429). These two factors - the author's modest role as a redactor, and the work's close connection to its community - rule out for Balz the possibility of the author including his name (p.429).

The most important treatment of the subject, and the first to treat anonymity as a separate topic in its own right, was an article by Michael Wolter in 1988. ${ }^{7}$ Wolter agrees with the previous authors on the fact of the Gospels' anonymity. The Gospels, along with Acts (which forms, with Luke, a single Doppelwerk), Hebrews and 1 John, are works 'die ursprünglich überhaupt keinen Verfassernamen genannt haben und darum als anonym zu bezeichnen sind' (p. 1). The idea that the titles are original 'steht heute ausser Frage' (p. 4). According to Wolter, anonymity differs from pseudonymity in that the latter seeks to establish continuity with apostolic tradition, while the anonymous literature of the NT seeks to ground Christ as the sole authority (p. 6). Wolter offers a sociological context for this contrast: the pseudepigraphical writings of the NT assume a settled Christian identity in need of preservation, while the anonymous works feel the need to provide a legimitation of Christian identity, especially in relation to Judaism. John's Gospel, for example, is an instance of an (originally) anonymous work in which Jesus rather than the author of the Gospel is the exclusive guarantor of Christian identity. (John 21, however, is a later pseudonymizing addition.) In Mark, too, only Jesus authorises the Gospel and legitimates a Christian identity which extends beyond Judaism (pp. 11-12). Luke-Acts is a slightly different case in that Luke 1.1-4 does tie the authority of the work to apostolic tradition, and Acts presents Jesus as the proclaimed rather than proclaimer; on the other hand, the aim of legitimizing a Law-free Gospel over against Judaism remains a constant (p. 13). Notably, Wolter remarks in his Fazit that the anonymity of the Gospels is not an anonymity in the sense that the particular author wants to remain unknown: 'das wäre viel zu modern gedacht' (p. 15).

\footnotetext{
${ }^{6}$ H. Balz, 'Anonymität und Pseudepigraphie im Urchristentum: Überlegungen zum literarischen und theologischen Problem der urchristlichen und gemeinantiken Pseudepigraphie', ZThK 66 (1969), pp. 403-436.

${ }^{7}$ M. Wolter, 'Die anonymen Schriften des Neuen Testaments. Annäherungsversuch an ein literarisches Phänomen', ZNW 79 (1988), pp. 1-16. Wolter criticises Aland's lumping of the two topics together (p. 3).
} 
A further significant contribution to the discussion stems from Armin Baum (2008), who brings anonymity further out of the shadow cast by pseudonymity. ${ }^{8}$ He talks of 'the striking fact that the NT Gospels and Acts do not mention their authors' names... only the NT letters and the Apocalypse were published under their authors' names while the narrative literature of the NT remained anonymous', citing at the beginning of his article an assertion about Luke by François Bovon: 'The absence of the author's name in Luke's prologue remains mysterious to me' (p. 120). He further notes it as a 'fact which has not sparked much interest among New Testament scholars' that the Gospels 'were written and published anonymously', especially given that they have prologues (pp. 121, 122). Baum, considering the Gospels and Acts to be 'history books' (so Baum's title), pays special attention to the fact that in Greco-Roman history writing, 'the Greek historian would mention his name and his provenance' (p. 125). As with the authors already considered, however, the absence of names is no accident, for the absence of titles was a common feature of ancient Near Eastern, and especially Old Testament, history writing. In the Old Testament, as in its literary environment, it was the subject matter which was important, not who wrote it. The same is true of the Gospels, where the evangelists 'regarded themselves as comparatively insignificant mediators of a subject matter that deserved the full attention of the readers' (p. 142).

There have been a few minor treatments which have not added significantly to what has been said by the protagonists expounded above. ${ }^{9}$ Despite the differences among these studies, some general points emerge. (i) These scholars highlight the topic as a neglected one. (ii) Aland and Balz treat anonymity in relation to pseudonymity, or even within it: certainly the latter dominates. In Wolter and especially in Baum, however, anonymity comes of age as a free-standing topic. (iii) All these scholars see the anonymity of the Gospels not merely as a publishing convention but as a function of the self-effacing posture of the evangelists. (iv) The principal reasons adduced for the Gospels' anonymity are the obvious absences of names within the text, as well as the lateness of the current titles: this is what they mean when they say that the Gospels were published anonymously.

\subsection{The Dissenting Few}

There have been a few dissenters from this line of scholarship. Kirsopp \& Silva Lake, for example, said of the titles: 'Why should this testimony not be accepted? No reason has ever been shown, for the view that antiquity tended to anonymous books is contrary to evidence, and it is most unlikely that the second Gospel, for instance, ever circulated without the name of Mark attached to it. ${ }^{10}$ Dibelius and Moles comment

\footnotetext{
${ }^{8}$ A.D. Baum, 'The Anonymity of the New Testament History Books: A Stylistic Device in the Context of Greco-Roman and Ancient Near Eastern Literature', NovT 50 (2008), pp. 120-142. He deals with pseudonymity in his monograph Pseudepigraphie und literarische Fälschung im frühen Christentum: Mit ausgewählten Quellentexten samt deutscher Übersetzung (Tübingen: Mohr, 2001).

${ }^{9}$ See e.g. the interesting discussion of the nature of authorship (especially as it relates to Acts) in A.J. Droge, 'Did "Luke" Write Anonymously? Lingering at the Threshold', in J. Frey, J. Schröter \& C.K. Rothschild (eds.), Die Apostelgeschichte im Kontext antiker und frühchristlicher Historiographie (Berlin: De Gruyter, 2009), pp. 495-518.

${ }^{10}$ K. Lake \& S. Lake, An Introduction to the New Testament (London: Christophers, 1948), p. 4.
} 
that the dedication to Theophilus in Luke's Gospel means that 'the name of the author could hardly be omitted from the title', and Luke's prologue demands a title with Luke's name, or else the first person references in Luke 1.1-4 'would be left hanging. ${ }^{11}$ Bauckham's surgical distinctions between the two Johns attested in the literature of the second century conclude of John's Gospel that 'that there is no evidence that the Gospel was ever regarded as anonymous' ${ }^{\prime 2}$ indeed, more positively, 'The fourth gospel was never anonymous. ${ }^{13}$ The most extensive protest against the anonymity theory is found in various studies by Martin Hengel, who argued that all

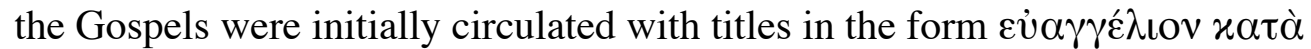
Mâ@xov etc. ${ }^{14}$ Hengel's arguments, some of which we shall revisit in due course, focus mainly on the practical necessity of the titles especially in the institutions of the library, the book-trade, and early Christian worship.

\subsection{Gospels Scholarship at Large}

Nevertheless, Gospels scholarship at large very much endorses the picture painted by Aland and the other studies devoted to anonymity. One scholar states with sovereign confidence: 'we know that the original manuscripts of the Gospels did not have their authors' names attached to them. ${ }^{15}$ More modestly, Mary Ann Tolbert says that the view that the Gospels were 'originally anonymous' is 'the most probable', ${ }^{16}$ and Bock and Wallace say the Gospels 'almost surely were anonymous when penned. ${ }^{17}$ After their composition, the four Gospels were 'anonym herausgegeben ${ }^{18}$ and then 'anonym überliefert'. ${ }^{19}$ The reasons for these judgments are the same two principal reasons that emerged in our survey of the specialist studies. (1) The first is the lack of inclusion of authors' names in the Gospels: 'they themselves do not tell us who their authors were. ${ }^{20}$ Or as some more crudely put it, the Gospels are not 'signed'. ${ }^{21}$ (2)

\footnotetext{
${ }^{11}$ Respectively, M. Dibelius, Studies in the Acts of the Apostles (London: SCM, 1956), p. 148, and J. Moles, 'Luke's Preface: The Greek Decree, Classical Historiography and Christian Redefinitions', NTS 57 (2011), pp. 461-482 (467).

${ }^{12}$ R.J. Bauckham, 'Papias and Polycrates on the Origin of the Fourth Gospel', JTS 44 (1993), pp. 24-69 (25). This essay is also reprinted, largely unchanged, in idem, The Testimony of the Beloved Disciple: Narrative, History, and Theology in the Gospel of John (Grand Rapids: Baker, 2007), pp. 33-72.

References to the essay henceforth will follow the pagination of the JTS article.

${ }^{13}$ Bauckham, 'Papias and Polycrates', p. 65.

${ }^{14}$ See M. Hengel, The Four Gospels and the One Gospel of Jesus Christ (London: SCM, 2000), p. 50 : they were 'not secondary additions but part of the Gospels as originally circulated'. That this refers to the individual Gospels (not the collection) is clear in his statements about Matthew (p. 77; cf. p. 97) and Luke (102-103). See also the questioning of anonymity in 'Die Evangelienüberschriften' (orig. 1984), in Hengel, Jesus und die Evangelien: Kleine Schriften V (Tübingen: Mohr, 2007), pp. 526-567 (542-543), and 565 on the origins of the titles at the point of the final editing and earliest circulation of the Gospels.

${ }^{15}$ B.D. Ehrman, Jesus: Apocalyptic Prophet of the New Millennium (Oxford: Oxford University Press, 1999), p. 42.

${ }^{16}$ M.A. Tolbert, Sowing the Gospel: Mark's World in Literary-Historical Perspective (Minneapolis: Fortress, 1989), p. 27.

${ }^{17}$ D. Bock \& D. Wallace, Dethroning Jesus (Nashville: Thomas Nelson, 2007), p. 127.

${ }^{18}$ A.F.J. Klijn, 'Die Entstehungsgeschichte des Neuen Testaments', ANRW II 26.1 (Berlin/ New York: De Gruyter, 1992), pp. 64-97 (79).

${ }^{19}$ W. Reinbold, Der Prozess Jesu (Göttingen: Vandenhoeck \& Ruprecht, 2006), p. 41.

${ }^{20}$ D. Senior, P.J. Achtemeier \& R.J. Karris, Invitation to the Gospels (New York/Mahwah: Paulist, 2002), 328. Cf. F.B. Watson, The Fourfold Gospel (Grand Rapids: Baker, 2016), p. 61, on Luke: 'The
} 
Added to this lack of self-reference is a claim about the $\varepsilon \dot{v} \alpha \gamma \gamma \varepsilon \dot{\varepsilon} \lambda$ ıov $\varkappa \alpha \tau \alpha$ X $\mathrm{X}$ titles: initially there was what Watson refers to as 'the anonymizing tendency of the earliest tradition' ${ }^{22}$ after that 'the present titles probably were not added until sometime in the second century, ${ }^{23}$ or even 'late in the second century' ${ }^{24}$ They were added when the Gospels began to circulate together and 'express the traditions that were current at that time. ${ }^{25}$ Freed rightly assesses the majority view, indeed near-consensus, among scholars: 'Most NT scholars agree that the gospels are anonymous and that the present titles probably were not added until sometime in the second century. ${ }^{26}$

\subsection{The approach in this article}

We are therefore left with two seemingly indisputable facts about the Gospels: (1) 'they themselves do not tell us who their authors were', and (2) 'the present titles probably were not added until sometime in the second century.' The first is indisputable, and although Hengel has made a fascinating case against (2), he has not really persuaded many others. Rather than disputing these two facts, then, what I wish to dispute in the rest of this article is their significance, and to argue that they are in fact entirely irrelevant to the question of the Gospels' anonymity.

\section{The Significance of the Absence of the Author's Name}

The first issue to address, then, is the significance of there being no named author in the prologue or epilogue to the text ('fact 1' noted just above). Rather than looking at the entirety of antecedent and contemporaneous literature from the Graeco-Roman world and the Near East, we can narrow the scope by sketching how names were employed in three of the main candidates in NT scholarship for the genre of the Gospels. Some have claimed that the Gospels are sui generis, but if this is the case then one cannot have any assumptions one way or the other. We will explore here the conventions about the presence or absence of the author's name in works which can be classified as technical treatise, history or biography.

\subsection{Technical Treatise}

We can treat this case briefly as it has only been applied to Luke. Alexander, in her arguments for the prologue of Luke's Gospel as a 'scientific' (in the sense of wissenschaftlich) preface mentions the absence of the name as a standard (non-)

\footnotetext{
third of the canonical gospels did not begin life as the work of "Luke," nor does it identify itself as a "gospel."... he does not give his own name.'

${ }^{21}$ G.E. Ladd, New Testament and Criticism (Grand Rapids: Eerdmans, 1967), p. 128; P. Achtemeier, J.B. Green \& M.M. Thompson, Introducing the New Testament: Its Literature and Theology (Grand Rapids: Eerdmans, 2001), p. 143.

${ }^{22}$ F.B. Watson, Gospel Writing: A Canonical Perspective (Grand Rapids: Eerdmans, 2013), p. 350.

${ }^{23}$ E.D. Freed, The New Testament: A Critical Introduction (Belmont: Wadsworth, 2000), p. 123.

${ }^{24}$ M.E. Boring \& F.B. Craddock, The People's New Testament Commentary (Louisville: WJK, 2009), p. 284.

${ }^{25}$ Boring \& Craddock, People's New Testament Commentary, p. 284.

${ }^{26}$ Freed, The New Testament, p. 123.
} 
feature of technical handbooks. ${ }^{27}$ In the appendix to an article on the subject, she gives in full four examples of scientific prologues: those to Diocles, Letter to Antigonus (iv BCE), Demetrius's Formae Epistolicae (i BCE), Hero of Alexandria's Pneumatica I (i/ii CE), and Galen's De Typis (ii CE) ${ }^{28}$ Of these authors, none mentions his own name except Diocles who begins his treatise with an epistolary address. Absence of the name from such treatises, then, is unremarkable, and if Luke's preface belongs in this tradition, then the absence of a name from it should not arouse comment.

\subsection{History}

As we saw in our survey of the specialist studies above, Baum particularly maintained that histories written in Greek included their authors' names, and so the absence of such names from the Gospels is a startling datum. The fountain-heads of Greek history-writing, Hecataeus of Miletus (vi-v BCE), Herodotus (v BCE) and Thucydides (v-iv BCE) announce themselves as authors in the prefaces to their works. ${ }^{29}$ Thereafter, there is a stronger preference among Greek historians for including names, than in, say, technical treatises. Baum's statement that Greek historians generally did this, however, stands in need of correction. There are three weaknesses in Baum's treatment of Greek and Roman literature that need to be noted.

First, there is a conflation in Baum's discussion of (a) the inclusion of the name within the work and (b) publication under one's own name. Baum's statement that Jason of Cyrene and Justus of Tiberias (about whose works we know almost nothing) along with Eupolemus, Artapanus and other Jewish historians did not write their works anonymously is probably true, but confusing following a statement about Josephus's inclusion of his actual name in a preface which is part of his Jewish War. We do not know if those other Jewish historians included their names in their works.

The second, more substantive difficulty concerns his assertion: 'At the beginning or end of his prologue, the Greek historian would mention his name and his provenance. ${ }^{30}$ Leaving aside the exaggeration about the frequency of provenance, the statement is also an over-generalisation about the presence of the name. ${ }^{31}$ There are plenty of counter-examples, instances of which are by no means obscure figures. There is a certain degree of unevenness in Baum's account: he remarks that Xenophon (iv BCE) used a pseudonym for the Anabasis, but Xenophon (if indeed he did publish the Anabasis under another name) did not include this name as the author

\footnotetext{
${ }^{27}$ L. Alexander, The Preface to Luke's Gospel: Literary Convention and Social Context in Luke 1.1-4 \& Acts 1.1 (Cambridge: CUP, 1993), pp. 98-99.

${ }^{28}$ L. Alexander, 'Luke's Preface in the Context of Greek Preface-Writing', NovT 28 (1986), pp. 48-74 (72-73).

${ }^{29}$ Hecataeus, FGrHist 1 F 1; Herodotus, Hist. 1, Preface; Thucy. Hist. 1.1.1. For later examples with the name included, see D. Fehling, 'Zur Funktion und Formgeschichte des Proömiums in der älteren griechischen Prosa', in K. Vourveris \& A. Skiadas (eds.), $\triangle \Omega P H M A$ : Hans Diller zum 70. Geburtstag. Dauer und Überleben des antiken Geistes (Athens: Griechische Humanistische Gesellschaft, 1975), pp. 61-75 (65); J. Marincola, Authority and Tradition in Ancient Historiography (Cambridge: CUP, 1997), pp. 271-275.

${ }^{30}$ Baum, 'The Anonymity of the New Testament History Books', p. 125.

${ }^{31}$ Also regarded too much as the norm in E. Herkommer, Die Topoi in den Proömien der romischen Geschichtswerke (Diss. Tubingen, 1968), pp. 46-52.
} 
within the text, and it should be added that his other works are unnamed..$^{32}$ Baum notes Josephus's self-reference in the preface to his Jewish War, but not the absence of his name from Antiquities of the Jews. Nor are there prefatory self-references in such notable Greek historians, roughly contemporaneous with Luke, as Polybius (ii BCE) and Diodorus Siculus (i BCE).$^{33}$ To these we can add Arrian (late i-ii CE), though admittedly in his case the absence is ostentatiously self-effacing. ${ }^{34}$ Therefore although one could talk of a possible tendency to include the name as an element of 'the prologue-form in ancient historiography', the title of Earl's article on the subject, he is undoubtedly correct that 'minor variations such as the position or even the inclusion of the author's name were allowable'. ${ }^{35}$

Thirdly, although Baum's treatment of the name appears in a section on GrecoRoman historiography, he mentions no histories in Latin, at least of a nonbiographical character. Among Roman historians, one can find major figures failing to include their names, including Sallust (i BCE), ${ }^{36}$ Livy (i BCE - i CE), Tacitus (i-ii $\mathrm{CE}$ ) and Florus (i-ii CE) ${ }^{37}$ Indeed, Herkommer notes that this is the norm. ${ }^{38}$

\subsection{Biography}

In some respects biography is a sub-genre of historiography, but it is treated separately here because of the different ways in which the sphragis may or may not be employed..$^{39}$ Moreover, it is probably true that the most popular view of the Gospels' genre (though not a consensus position) is that they most closely approximate to bioi. In this connection it is important to note that Philo omits his name from his biographically oriented works on Abraham, Joseph and Moses. Josephus's autobiography does not contain a preface mentioning the subject's name,

\footnotetext{
${ }^{32}$ That Xenophon did publish the Anabasis pseudonymously (a point first made by Plutarch) is questioned by e.g. M. Flower, Xenophon's Anabasis, Or The Expedition of Cyrus (Oxford: Oxford University Press, 2012), pp. 53-54. Further, C. Pelling, 'Xenophon's and Caesar's third-person narratives - or are they?', in A. Marmodoro \& J. Hill, eds. The Author's Voice in Classical and Late Antiquity (Oxford: Oxford University Press, 2013), pp. 39-73 (41 n. 8): 'Unlike Herodotus and Thucydides, Xenophon does not name himself at the beginning of his text in Hellenica or in Anabasis: might this suggest a shift in paratextual conventions, with the author's name now stated along with the title before the text?'

${ }^{33}$ D. Earl, 'Prologue-Form in Ancient Historiography', ANRW I 2 (Berlin/ New York: De Gruyter, 1972), pp. 842-56 (843), notes Diodorus and Polybius. S.A. Adams, 'Luke's Preface and its

Relationship to Greek Historiography: A Response to Loveday Alexander', JGRChJ 3 (2006), pp. 177191, 181, also notes Dionysius, but see Ant. Rom. 1.8.4.

${ }^{34}$ Moles, 'Luke's Preface', 467. See further S. Swain, 'The Hiding Author: Context and Implication', in A. Kahane \& A. Laird (eds.), A Companion to the Prologue of Apuleius' Metamorphoses (Oxford: Oxford University Press, 2001), pp. 55-63 (56-58).

${ }^{35}$ Earl, 'Prologue-Form in Ancient Historiography', p. 843.

${ }^{36}$ Moles, 'Luke's Preface', p. 467, noting Livy and Sallust.

${ }^{37}$ Earl, 'Prologue Form in Ancient Historiography', p. 843.

${ }^{38}$ Herkommer, Topoi in den Prö̈mien, 48-49 notes that unlike some Greek historians, Roman historians did not usually include their names in their works. Similarly, Alexander, Preface to Luke's Gospel, p. 27.

${ }^{39}$ In Classical scholarship, the author's reference to his name in the text is often called, following

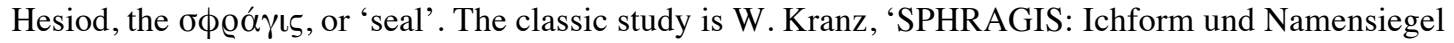
als Eingangs- und Schlußmotiv antiker Dichtung', Rheinisches Museum für Philologie NF 104.1 (1961), pp. 3-46. See now I. Peirano, “Sealing” the book: the sphragis as paratext', in L. Jansen (ed.), The Roman Paratext (Cambridge: Cambridge University Press, 2014), pp. 224-242.
} 
so if absence of such a self-reference were a criterion for anonymity we would be left with the absurd result that Josephus's Vita was anonymous. Among well-known biographers Plutarch (i-ii CE) makes no mention of his name in his Parallel Lives. Of the biographical writings of Lucian (ii CE), his Passing of Peregrinus has his name, but as part of an epistolary prescript ('Lucian to Cronus, with best wishes'); otherwise, Alexander the False Prophet, the Toxaris and the biography of Demonax have no mentions of Lucian's name in a preface. In the Alexander, Lucian's name appears towards the end merely because he is a participant in the drama (Alex. 55), and similarly Porphyry's Life of Plotinus (iii CE) only features its author when Porphyry's relationship with his subject intrudes into the narrative. Accordingly, his Life of Pythagoras does not mention Porphyry by name. The Life of Apollonius by Philostratus (ii-iii CE) and two works entitled Lives of the Sophists, one by him and another by Eunapius (iv-v CE), do not. Similarly, on the Roman side, Nepos (i BCE) makes no mention of his name in his preface. The Agricola (late i CE) makes no mention of Tacitus himself, although the mention that the author is the subject's sonin-law means that the writer's identity is not in doubt (Agr. 3). The opening pages of Suetonius' Lives of the Caesars (ii CE) are lost, and with them any possibility of our knowing whether he mentioned his name..$^{40}$ Lucian's Passing of Peregrinus is one of only two examples of a biographical work which I have found with a prefatory mention of the author, and this in a very different form from the self-descriptions of Herodotus and Thucydides. The other instance is a fictional one, in the biography of Aelius in the Historia Augusta. This second biography in the sequence uniquely but spuriously begins: 'To Diocletian Augustus, his Aelius Spartianus, greetings'.

\subsection{Assessing the Significance of the Absence of the Name}

This article is not the place for arguing a particular case for the genre of the Gospels, hence the spread of treatments here. What emerges is that the absence of the name from a technical prologue (if that is what Luke's is) would be entirely unremarkable. If belonging to the historiographical genre, the Gospels might be regarded as rather coy examples, but are certainly within the acceptable spectrum of possibilities. Finally, if - as most maintain - they are closest to being bioi, the absence of the evangelists' names should excite no comment at all. Such an absence is not remotely a 'curious feature'. ${ }^{41}$

The absence of a name within the body of an ancient work is entirely understandable because of all the other ways in which the author might be identified. There were of course numerous ways of indicating an author's name in or on a roll or codex, outside of the work itself. To name a few examples, ${ }^{42}$ the name might appear (i) in a superscription or initial title above the main body of the work proper, ${ }^{43}$ (ii) in a list of

\footnotetext{
${ }^{40}$ According to M. Meckler, 'The Beginning of the "Historia Augusta"”, Historia 45.3 (1996), pp. 364375 (365 n. 5), Suetonius's work is reported by John Lydus as having been dedicated to the praetorian prefect Septicius, but this of course does not necessitate a reference to Suetonius's own name. The works of Marius Maximus (ii-iii CE) are lost in their entirety, although quotations appear in the Historia Augusta.

${ }^{41}$ Pace Droge, 'Did “Luke” Write Anonymously?', p. 495.

${ }^{42}$ For a study of (i) to (iv) with reference to Gospel manuscripts, see S.J. Gathercole, 'The Titles of the Gospels in the Earliest New Testament Manuscripts', ZNW 104 (2013), p. 33-76.

${ }^{43}$ See e.g., with respect to rolls, M. Caroli, Il titolo iniziale nel rotolo librario greco-egizio: Con un catalogo delle testimonianze iconografiche greche e di area vesuviana (Bari: Casanova, 2007).
} 
the contents of the work (the capitula list) preceding the main body of the text, (iii) in a running header, (iv) as an end title, in a subscriptio or longer colophon appended after the end of the work. ${ }^{44}$ Other methods included (v) title pages, ${ }^{45}$ or (vi) the inscription of the author's name on the back of the roll, or (vii) a 'name tag' inserted into the roll, in a form rather like the modern book-mark (called variously silluboi or sittuboi) ${ }^{46}$ Some of these seem intuitively improbable, only coming in later in the transmission of the Gospels (such as ii) along with (iii) and (v) which are more allied to the codex form. Moles seems to suggest the last option (vii), i.e. a sittubos: 'his [sc. Luke's] name must have been inscribed on the titulus attached to the physical book. ${ }^{, 47}$ We do not of course know if or how any of these were used in the first copies of the Gospels, but the point here is merely to emphasise the irrelevance of the fact that the author's names are absent from the prefaces in the Gospels. As Herkommer noted years ago, the introduction of titles and authors' names separate from the work itself rendered superfluous (even if it did not eliminate) the personal self-introduction. ${ }^{48}$

In overall conclusion to this second part, one can at least say that it is a category mistake to say that a work is anonymous because it does not contain within it the name of the author. As Simon Swain has commented about Greek and Latin literature in general: 'It is perfectly normal for literary works to begin without a reference to their author. The author's name should already be known to the reader or hearer from the usual devices. ${ }^{49}$

\section{Were the Titles or Names Later Additions?}

If the first item of evidence for the Gospels' anonymity is insignificant, what then of the second challenging datum: 'the present titles probably were not added until sometime in the second century' (the formulation of Freed quoted above, in his representation of the majority view). This again may well be true. It is not clear that

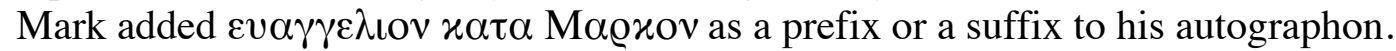
This observation, however, is also irrelevant to the question of whether there was

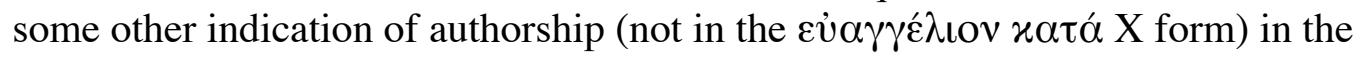
paratexts to the Gospel compositions. Irrespective of whether the full title was absent, the author's name might in any case have been appended somehow.

There are three ways to address this question of whether it was probable that there were indications of authorship from the beginning, namely (3.1) by arguments from practical necessity, and (3.2) by the evidence from the earliest period for names being assigned to Gospels. A final section (3.3) will offer some further corroborating evidence.

\footnotetext{
${ }^{44}$ See e.g. F. Schironi, TO MEГA BIB $\Lambda I O N$ : Book-ends, End-titles, and Coronides in Papyri with Hexametric Poetry (Durham, NC: American Society of Papyrologists, 2010).

${ }^{45}$ See S.J. Gathercole, 'The Earliest Manuscript Title of Matthew's Gospel (BnF Suppl. gr. 1120 ii 3 / ?P4)', NovT 54 (2012), p. 209-235.

${ }^{46}$ T. Dorandi, 'Silluboi', Scrittura e Civiltà 8 (1984), p. 185-199.

${ }^{47}$ Moles, 'Luke's Preface', p. 467.

${ }^{48}$ Herkommer, Die Topoi in den Prö̈mien, p. 48. See also the statement by Pelling in n. 32 above.

${ }^{49}$ Swain, 'The Hiding Author', p. 55.
} 


\subsection{Practical Necessity}

We can return to Martin Hengel's three suggested settings requiring titles mentioned earlier. In two cases, namely the importance of titles for (i) the book trade and (ii) libraries, it is hard to see the significance for the period at the beginning (when the Gospels were first distributed) with which we are concerned here. It is not until the second century that appeal is made to the public availability of Christian books (although it is quite early in the second century).$^{50}$ Similarly, Christian libraries proper probably began around the same time, although it is likely that some teachers (like the evangelists) and churches possessed a number of Christian books, and it is easy to imagine that there they had means of identifying the different volumes ${ }^{51}$ Potentially more significant is (iii) the setting of Christian worship: Hengel adduces, for example, the comment at the beginning of Melito's Peri Pascha that 'Exodus has been read' and Luke 4, in which a scroll identifiable as that of Isaiah is handed to Jesus. Even here, however, a nameless title 'Gospel' would be sufficient as long as only one Gospel was in use - just as 'Exodus' was sufficient.

Perhaps more important is the common-sense speculation that when Gospels left their original contexts and were read elsewhere, it is hard to imagine at least some hearers not thinking 'Says who?' Hengel's point about anonymous writings potentially inviting suspicion is relevant here. Even before the presence of multiple Gospels in one congregation, Christians might well have wanted to know where a $\varepsilon \dot{v} \alpha \gamma \gamma \varepsilon \dot{c} \lambda \iota 0 v$ came from. Hence it is not necessarily the case that names must only have become a concern at the earliest when two or more Gospels were gathered together, as Wolter avers. $^{52}$

What has not, to my knowledge, been considered in the literature on this topic is the relevance of this point to the use of Mark by the authors of Matthew's and Luke's Gospels. ${ }^{53}$ One could, conceivably, argue that both these later evangelists were struck by the 'ring of truth' in Mark's Gospel, and so for that reason followed it closely. More probably, Matthew and Luke, for all their sense that Mark needed adaptation and expansion, followed Mark so closely in order and content because they had received reports about it which inspired some confidence. ${ }^{54}$ Minimally, this is likely to have been a name. It is one thing to assume that Christians in a first-century congregation would simply have taken on trust what they heard read out, without asking the 'says who?' question. It is a considerable step beyond that - and beyond what I at least can believe - to suppose that a professedly conscientious investigator like Luke would, without any accompanying testimony, follow (by ancient standards, very closely) a naked anonymous account. It seems far more likely that Luke and Matthew would have received, alongside Mark's Gospel, some statement - oral or paratextual - about what and whose it was. The first readers and audience of Mark's Gospel would have known who wrote it, and the distance in time between Mark and

\footnotetext{
${ }^{50}$ Aristides, Apol. 15-16 presuppose the availability of the Gospel(s) and Christian writings to the emperor Hadrian around $125 \mathrm{CE}$.

${ }^{51}$ See further M. Hengel, Studies in the Gospel of Mark (London: SCM, 1985), pp. 77-78.

${ }^{52}$ Wolter, 'Die anonymen Schriften', p. 4.

${ }^{53}$ I leave aside here views according to which Luke also used Matthew (or vice versa).

${ }^{54}$ For an illustration of Matthew's and Luke's close adherence to Mark's order, see Mk 8.279.48//Matt. 16.13-18.9//Lk. 9.18-50: a helpful table is presented in M.S. Goodacre, The Synoptic Problem: A Way through the Maze (London: Continuum, 2001), p. 18.
} 
his Synoptic successors was not very great (Mark is rarely considered to be much more than about 15 years earlier than Matthew and Luke). As we saw Wolter noting earlier, it is not the case that the author wished to remain unknown - there is no evidence for a desire for self-effacing secrecy. ${ }^{55}$

We can look at this another way, not from the perspective of Matthew's or Luke's use of Mark, but from the angle of the transportation of Mark's Gospel. How did Mark reach Matthew and Luke? Books in the ancient world did not simply float around. They were copied by trained scribes, and would have been carried transprovincially by trusted people. For Matthew in (let us say) Antioch to have got hold of Mark written in (let us say) Rome, the text must come either directly or indirectly from Rome to Antioch. It is likely that not only the initial audience and the first readers of Mark would have known the author's identity, but also the earliest copyists and carriers. Again, the distance in time between Mark on the one hand, and Matthew and Luke was not very great.

\subsection{Early evidence for named evangelists}

As far as I am aware, there is not a clear account collecting together the testimonia to the four evangelists as Gospel-writers in the first and second centuries. This is a different kind of exercise from that of offering arguments for a fourfold Gospel canon, because attestation of content is not sufficient here. Hannah's discussion of the fourfold Gospel canon in the Epistula Apostolorum, for example, is based on the Epistula's knowledge of some of the contents of the four canonical Gospels. ${ }^{56}$ The same applies to Stanton's arguments for Justin. ${ }^{57}$ For the purposes of the arguments here, by contrast, named testimonia are what are needed, although in some cases the arguments rely also on indirect evidence for a work's attestation of a named Gospel author. Working backwards from the rather arbitrary date of the end of the second century, it is potentially misleading to present Irenaeus as a novum, because he is merely one of several second-century writers noting evangelists's names. ${ }^{58} \mathrm{We}$ will also introduce here two testimonia not regularly noted in these discussions.

\footnotetext{
${ }^{55}$ Wolter, 'Die anonymen Schriften', p. 15.

${ }^{56}$ D.D. Hannah, 'The Four-Gospel "Canon” in the Epistula Apostolorum', JTS 59 (2008), pp. 598-633.

${ }^{57}$ G.N. Stanton, Jesus and Gospel (Cambridge: CUP, 2004), pp. 92-105.

${ }^{58}$ Others have proposed some additional works as containing potential testimonia. See e.g. M. Hengel, The Johannine Question (London: SCM, 1989), p. 74 and R.J. Bauckham, Jesus and the Eyewitnesses (Grand Rapids: Eerdmans, 2006), p. 464, on Ep. Ap. 2.1. I am not quite convinced that this is sufficient evidence, though it is quite plausible that the author would assume an identification. Some e.g. Hengel, Four Gospels, 21, have argued that Gaius and the "Alogoi" in the second century claimed that the fourth Gospel was not written by John but by Cerinthus. However, both the dating of Gaius's floruit to the second century and the authenticity of his attribution of the Gospel (and not just the Apocalypse) to Cerinthus are questionable: see S. Manor, Epiphanius' Alogi and the Johannine Controversy (Leiden: Brill, 2016), pp. 60-74, on both the date of Gaius's work (early iii) and the authenticity of the Cerinthus attribution to the Gospel. See also as a possibility Epiphanius's Asian source, probably from the late second or third century: C.E. Hill, The Johannine Corpus in the Early Church (Oxford: Oxford University Press, 2004), p. 138. Since these are all potential testimonia to John, which are plentiful elsewhere, they would not greatly affect the picture in this article. Tertullian could also have been included, but his works mentioning the evangelists lie just outside the time-frame: John is first mentioned in Praescr. 22.5 (c. 203), and they all appear in Marc. 4.2.2 and thereafter. The Adversus Marcionem as we have it in its third edition dates to $c .207-208$, although its first edition appeared 'perhaps as early as 198', according to Tertullian: Adversus Marcionem, ed. and trans. E. Evans
} 
The first two testimonia we can note which might well derive from the second century are two manuscripts:

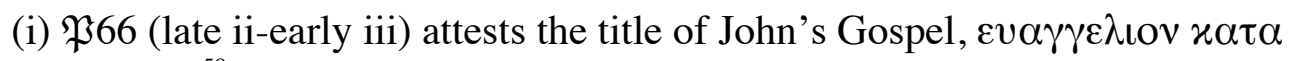
[ı] $\omega \alpha \nu v \eta v .^{59}$

(ii) Secondly, a flyleaf amongst the $\mathfrak{P} 4$ fragments may also date to the late second

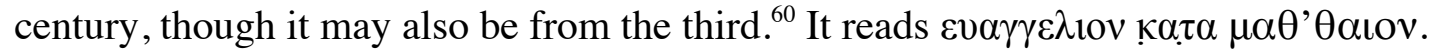

The rest of the evidence comes from second century literature, broadly understood to include letters and other documentary sources.

(iii) Fairly securely dated right at the end of the second century (and in one case, into the third) are Clement of Alexandria's statements of the evangelists as Gospel writers. The earliest references to authors of the Gospels are Matthew in Stromata I (c. 198), Mark in Quis dives salvetur (c. 203), Luke in Paedagogus (c. 197), and John in Protrepticus (c. 195). ${ }^{61}$

(iv) There are several other references specifically to John from around this time, which identify John as the beloved disciple who reclined at Jesus' side (Jn 13.25; 21.10), and therefore as the author of the Gospel (21.24). One of these has, to my knowledge, hitherto been missed. In a scene in the Nag Hammadi Acts of Peter and the Twelve (second half/ end of the second century ${ }^{62}$ ), Jesus gives the apostles a pouch of medicine, and tells them: 'Heal all the sick of the city who believe in my name.' Not being medically trained, the disciples are baffled by this. Peter does not want to ask Jesus how this could be possible, so he signals to John, who is next to Jesus, and tells him to ask Jesus about it. John then does so:

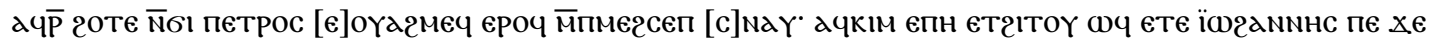

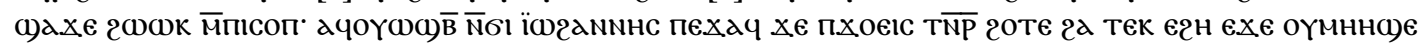
$\overline{\mathrm{N}}$ )axe... (AcPetTwelve 11.1-8)

Peter was afraid to reply to him again. He motioned to the one who was beside Jesus, which was John: 'You speak this time.' In response, John said, 'Lord, we are afraid to say many words in your presence...'

The scene seems to recall John 13.22-25, where the disciples are also baffled by what Jesus has said. There too Peter does not ask Jesus himself for an explanation, but motions to the beloved disciple - who is next to Jesus - to ask him, which the beloved

(Oxford: Clarendon, 1972), p. xviii.

${ }^{59}$ Gathercole, 'The Titles of the Gospels', p. 37-38.

${ }^{60}$ Gathercole, 'The Titles of the Gospels', p. 38; see further, idem, 'Earliest Manuscript Title of Matthew's Gospel', pp. 209-235.

${ }^{61}$ Strom. 1.21.147.5; Quis 5.1; Paed. 2.1.15.2; Protr. 4.59.3. Dates in J. Ferguson, Clement of Alexandria (New York: Twayne Publishers, 1974), pp. 16-17. See Hill, Johannine Corpus, pp. 121-122 for possible earlier dates.

${ }^{62}$ See P. Nagel, Codex apocryphus gnosticus Novi Testamenti (WUNT 326; Tübingen: Mohr, 2014), p. 348 (mid-late second century); M. Scopello, 'Introduction', in M. Meyer (ed.), Nag Hammadi Scriptures (New York: HarperOne, 2007), p. 359 (end ii/ beginning iii); A.L. Molinari, The Acts of Peter and the Twelve Apostles (NHC 6.1) (Atlanta: Society of Biblical Literature, 2000), pp. 201-233 provides a helpful overview of the various scholarly attempts to date the work, and an argument (which is by no means decisive) for a post-Decian date. 
disciple then does. Seeing John as the one 'beside Jesus', the Acts of Peter and the Twelve Apostles thereby sees John as the beloved disciple and therefore the author of the Gospel.

(v) In the Quartodeciman controversy, Polycrates of Ephesus wrote a letter $\left(190 \mathrm{~s}^{63}\right)$ to Victor of Rome stating that the paschal feast should always be celebrated on the 14th day. He writes of various local luminaries, buried in Asia, who observed this practice. One was John, here identified as the beloved disciple who reclined at the Lord's side, and therefore also as the author of the fourth Gospel: ${ }^{64}$

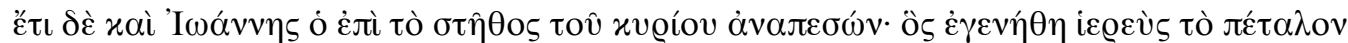

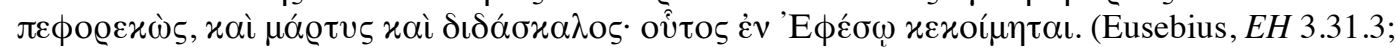
5.24.3-4)

In addition there was also John, who reclined on the Lord's chest, and who became a priest wearing the mitre, and a witness and a teacher. He sleeps at Ephesus.

(vi) The Muratorian Fragment (end $\mathrm{ii}^{65}$ ) refers to Luke and John by name, but since it names them as the third and fourth evangelists, it is all but certain that Matthew and Mark are mentioned in the lost section preceding.

(vii) Irenaeus (writing $c$. 174-189 $\mathrm{CE}^{66}$ ) refers several times to Matthew, Mark, Luke and John (e.g. AH 3.1.1). In Irenaeus we also have clear connections between these authors and the Gospels which we know under these names because he refers to the beginning of each Gospel in connection with each name (AH 3.11.8).

(viii) An indisputable testimonium to John's authorship of the fourth Gospel appears in Theophilus of Antioch's Ad Autolycum (c.180 CE): ${ }^{67}$

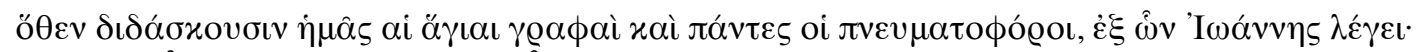

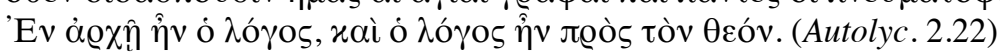

Therefore the Holy Scriptures teach us, as do all those inspired by the Spirit, one of whom, John, says, 'In the beginning was the Word, and the Word was with God.'

(ix) Hill, following Lawlor, notes an interesting passage from a historical epitome citing Hegesippus $(c .175-180)^{68}$ which is relevant for our purposes because it names John as apostle and evangelist in the sense of Gospel-writer: ${ }^{69}$

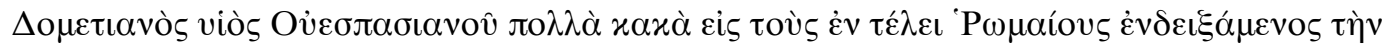

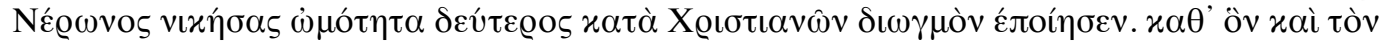

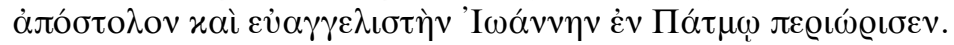

Domitian son of Vespasian displayed many evils against those in office in Rome, and beating Nero in cruelty he was the second to institute a persecution against Christians. At that time he imprisoned John, apostle and evangelist, on Patmos... ${ }^{70}$

\footnotetext{
${ }^{63}$ Bauckham, 'Papias and Polycrates', p. 28.

${ }^{64}$ Bauckham, 'Papias and Polycrates', p. 31.

${ }^{65}$ B.M. Metzger, The Canon of the New Testament: Its Origin, Development, and Significance (Oxford: Oxford University Press, 1997) pp. 191, 194. Arguments for the later date have not proven convincing.

${ }^{66}$ Irenaeus (AH 3.3.3) mentions bishop Eleutherius (174-189 CE) as current, but not his successor Victor.

${ }^{67}$ Theophilus's chronicle in Autolyc. 3.28 implies composition in 180 CE.

${ }^{68}$ Hill, Johannine Corpus, p. 88.

${ }^{69}$ The reference to an evangelist in the New Testament sense of the term (Ac. 21.8; Eph. 4.11; 2 Tim.

4.5) would be redundant after 'apostle'.
} 
Lawlor argues persuasively that a direct literary relationship between Eusebius and the epitome is unlikely, and that both are dependent upon Hegesippus. ${ }^{71}$

(x) In the Preface to the Chronicon Paschale, the Peri Pascha by Claudius Apollinaris of Hierapolis $(c .175)^{72}$ is cited:

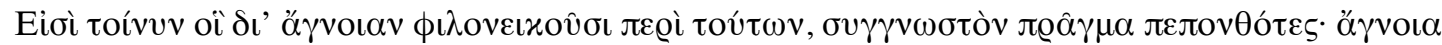

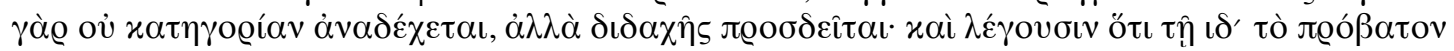

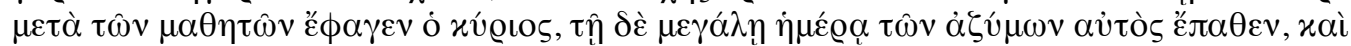

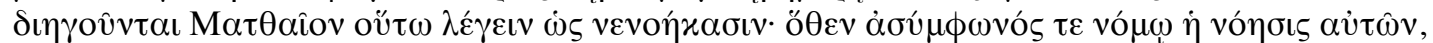

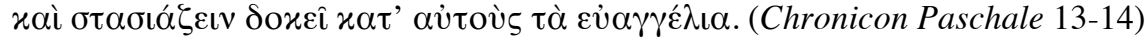

There are, then, those who out of ignorance stir up disputes about these this, even if what they do is pardonable. For ignorance does not deserve condemnation but needs instruction. And they say that on the fourteenth day the Lord ate the lamb with the disciples, and he himself suffered on the great day of the feast of unleavened bread. They explain that Matthew says this, or so they think. Therefore it is case both that their opinion disagrees with the Law, and that the Gospels seem to contradict them. ${ }^{73}$

Apollinaris here opposes the view, apparently based on the Synoptic chronology specifically in Matthew (26.17-19), that Jesus ate the Passover with his disciples on 14th Nisan. Elsewhere he maintains that Jesus died on this date.

(xi) The Acts of John (c. 150-20074), like Polycrates and the Acts of Peter and the Twelve, shows knowledge of the tradition that the beloved disciple was John (Ac. Jn 89), the son of Zebedee (Ac. Jn 88).

(xii) Heracleon $\left(c .150-175^{75}\right)$ comments that Jn 1.18 is spoken 'not by the Baptist but by the disciple' (Comm. John, fr. 3) ${ }^{76}$ It is not quite as certain as Gunther claims that Heracleon 'attributed the Gospel to John, "the disciple of the Lord", ${ }^{77}$ but it seems probable that he avoids calling either the Baptist or the evangelist 'John' to avoid confusion, especially given that 'John' is what Heracleon usually calls the Baptist.

\footnotetext{
${ }^{70}$ For the text, see J.A. Cramer (ed.), Anecdota Graeca, vol. 2 (Oxford: The University Press, 1835), p. 88 and C. de Boor, Neue Fragmente des Papias, Hegesippus und Pierius in bisher unbekannten Excerpten aus der Kirchengeschichte des Philippus Sidetes (TU V/ 2; Leipzig: Hinrichs, 1888), p. 169. ${ }^{71}$ See H.J. Lawlor, Eusebiana: Essays on the Ecclesiastical History of Eusebius (Oxford: Clarendon, 1912), pp. 40-56. This whole section is a series of brilliant pieces of detection. For a different view, see R.J. Bauckham, Jude and the Relatives of Jesus in the Early Church (Edinburgh: T \& T Clark, 1990), p. 97.

${ }^{72}$ R.M. Grant, Second Century Christianity: A Collection of Fragments (Louisville: WJK, 2003), p. 175, has $c$. 175. Eusebius (HE 4.19.1-21.1) puts Apollinarius's floruit in the time of Soter (c. 168174), and his composition of an apology to Marcus Aurelius (161-180 CE) is also indicative of his dates (HE 4.27.1). See further on Apollinaris, R.M. Grant, Greek Apologists of the Second Century (London: SCM, 1988), pp. 83-91.

${ }^{73} \mathrm{Tr}$. mine. On the passage, see further See U. Huttner, 'Kalender und religiöse Identität: Ostern in Hierapolis', ZAC 15.2 (2011), pp. 272-290.

${ }^{74}$ Acta Iohannis: Textus Alii - Commentarius - Indices, eds. E. Junod \& J.-D. Kaestli (CCSA 2; Turnhout: Brepols, 1983), p. 700, gives a date of 150-200 CE.

${ }^{75}$ Grant, Second Century Christianity, p. 70, talks of Heracleon being active in the third quarter of the century.

${ }^{76}$ The Fragments of Heracleon, ed. A.E. Brooke (Texts and Studies 1.4; Cambridge: Cambridge University Press, 1891), p. 55.

${ }^{77}$ J.J. Gunther, 'Early Identifications of Authorship of the Johannine Writings', JEH 31 (1980), pp. 401-427 (425).
} 
(xiii) According to Irenaeus, the exegesis of John 1 by the Valentinian theologian Ptolemy (c. 150-175) consisted in an exposition of how the Father emanated all things spermatically:

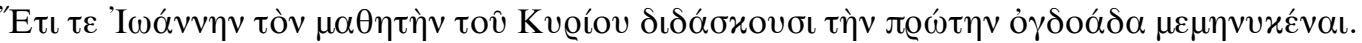

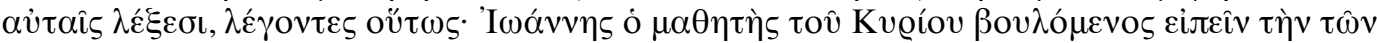

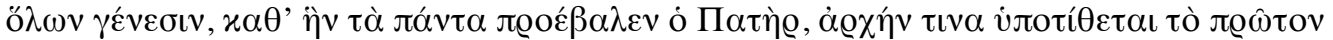

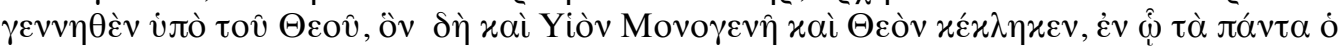

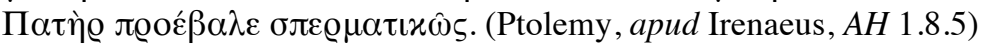

Further, they teach that John, the disciple of the Lord, pointed to the first Ogdoad, saying as follows, in these words: 'John, the disciple of the Lord, wanted to describe the origin of all things, that is, how the Father emanated everything. Therefore he lays down a certain principle, namely that which was firstbegotten by God, which Being he has called both the only-begotten Son and God. In him, the Father emanated all things spermatically...'

In this passage, Irenaeus is not paraphrasing, but quoting, 'in these words' ( $\alpha \dot{v} \tau \alpha \hat{\varsigma} \zeta$ $\left.\lambda \hat{\varepsilon}^{\xi} \xi \varepsilon \sigma \mathrm{l}\right)$. The content of the teaching about the only-begotten Son and God is sufficient to establish that John's Gospel is in view. This is confirmed by named citations of John 1.1-4 and 14: 'Thus John', Ptolemy writes, 'spoke about the first Ogdoad, the mother of the aeons' ${ }^{78}$

(xiv) Another neglected testimonium is the probable allusion to Matthew the evangelist in the Gospel of Thomas (c. 140-180): ${ }^{79}$

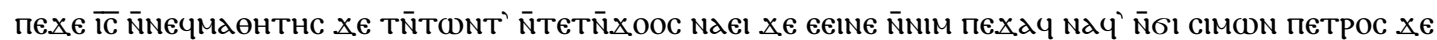

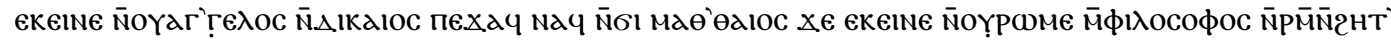

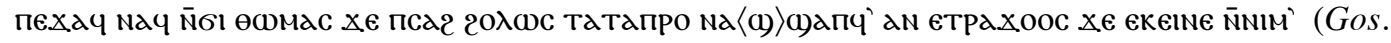
Thom. 13.1-4)

Jesus said to his disciples, 'Compare me and tell me whom I resemble.' Simon Peter said to him, 'You are like a righteous angel.' Matthew said to him, 'You are like a wise philosopher.' Thomas said to him, 'Master, my mouth is completely unable to say whom you are like.'

The view that this is a reference to Matthew the evangelist now has considerable scholarly support. ${ }^{80}$ A lengthy case has been made elsewhere,${ }^{81}$ but the key point is that here Matthew seems to be an authoritative spokesman, alongside Peter, who needs to be rebutted by the Gospel of Thomas. The reference to Matthew here also appears in a logion heavily influenced by Matthew's Gospel. ${ }^{82}$ Some have also suspected that the reference on Matthew's part to Jesus as a 'wise philosopher' might

\footnotetext{
${ }^{78}$ In his Epistle to Flora (apud Epiphanius, Pan. 33.3.6), Ptolemy also calls the author of the Gospel an apostle.

${ }^{79}$ It is not mentioned as a testimonium in Hengel, Four Gospels, for instance.

${ }^{80}$ A.F. Walls, 'References to the Apostles in the Gospel of Thomas', NTS 7 (1960-1961), pp. 266-270;

E. Haenchen, 'Literatur zum Thomasevangelium (Fortsetzung)', ThR 27 (1961), pp. 306-38 (315);

T.V. Smith, Petrine Controversies in Early Christianity (Tübingen: Mohr, 1985), pp. 115-116; R. Trevijano Etcheverría, 'Santiago el Justo y Tomás el Mellizo (Evangelio de Tomás, Log 12 y 13)', Salmanticensis 39 (1992), pp. 97-119 (112); E.H. Pagels, Beyond Belief: The Secret Gospel of Thomas (New York: Random House, 2003), p. 47 (tentatively); R.J. Bauckham, Jesus and the Eyewitnesses: The Gospels as Eyewitness Testimony (Grand Rapids: Eerdmans, 2006), pp. 236-237; G.W. Most, Doubting Thomas (London/ Harvard: Harvard University Press, 2005), p. 93; S.J. Gathercole, The Composition of the Gospel of Thomas (Cambridge: CUP, 2012), pp. 169-174; idem, The Gospel of Thomas: Introduction, Translation and Commentary (Leiden: Brill, 2014), pp. 259-266; Watson, Gospel Writing, p. 230.

${ }^{81}$ See e.g. Gathercole, Composition of the Gospel of Thomas, pp. 169-174.

${ }^{82}$ Gathercole, Composition of the Gospel of Thomas, pp. 174-177.
} 
reflect a perspective on the christology of Matthew. ${ }^{83}$ Matthew is known for little else in early Christianity besides being an evangelist, and so there is a high degree of probability that this dialogue in Thomas presupposes not just a Gospel attributed to Matthew, but one which has attained a certain level of authority.

(xv) Papias clearly attests to both Mark and Matthew as Gospel writers. Fragments of his comments are preserved by Eusebius, who only includes a fraction of what Papias says about these evangelists, as is evident from the Matthean extract, which begins with oûv. ${ }^{84}$

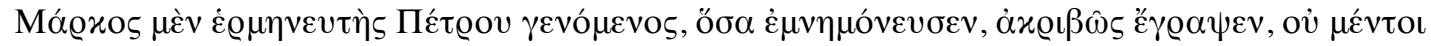

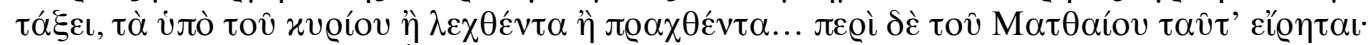

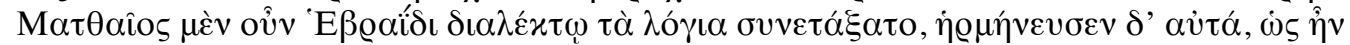

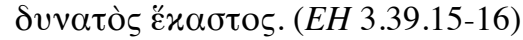

'Mark was Peter's interpreter, and whatever he remembered, he accurately wrote down the things said and done by the Lord, but not in order...'. About Matthew this is what is said: 'Matthew therefore arranged the oracles in the Hebrew language, but each person interpreted them according to his lights.'

Some have argued further for Papias's knowledge of John as an author. ${ }^{85}$ There is a good probability of this, since Papias's fragments seem to display dependence upon John: the order in Papias's list of disciples is striking in this regard, following the orders in John 1 and 21. Furthermore, the implication of disorder in Mark's Gospel presupposes knowledge of a Gospel with a different ordering of events, and the list of disciples suggests Papias's preference for Johannine sequence. This may be confirmed by the Muratorian Fragment's remark that John wrote down Jesus' deeds 'in their order' (Mur. Fr. 33), a point probably dependent upon Papias. ${ }^{86}$ The similarity of the accounts of John's Gospel-writing in the Muratorian Fragment and Clement's account of the ancient elders (which may also be dependent on Papias) suggests the existence of an explanation by the bishop of Hierapolis of the circumstances of the composition of John ${ }^{87}$ There are two more clear pieces of evidence. One garbled fragment of Papias, despite its howlers on many points, evidently makes reference to John: 'The Gospel of John was made known and given to the churches by John while still in the body... as one called Papias of Hierapolis, a disciple dear to John, reports in his five <exegetical> books. ${ }^{, 88}$ Another fragment quite independently states that one of the five books discussed John's Gospel, with John's Gospel containing the pericope adulterae ${ }^{89}$ Some also argue for Papias having discussed Luke, though this is more uncertain. ${ }^{90}$

\footnotetext{
${ }^{83}$ Bauckham, Jesus and the Eyewitnesses, pp. 236-237.

${ }^{84}$ Bauckham, 'Papias and Polycrates', p. 46.

${ }^{85}$ See C.E. Hill, "The Orthodox Gospel”: The Reception of John in the Great Church Prior to Irenaeus', in T. Rasimus (ed.), The Legacy of John: Second-Century Reception of the Fourth Gospel (Leiden: Brill, 2010), pp. 233-300 (286), for a list of other scholars.

${ }^{86}$ Bauckham, 'Papias and Polycrates', pp. 53-56.

${ }^{87}$ Clement, citing the ancient elders in the Hypotyposes, apud Eusebius, EH 6.14.7. It is possible, however, that Clement is writing independently of Papias, in which case his testimonium would be independent.

${ }^{88}$ Holmes, fr. 19: The Apostolic Fathers, ed. and trans. M.W. Holmes, 3rd edn. (Grand Rapids: Baker, 2007), p. 756.

${ }^{89}$ Holmes, fr. 23: see The Apostolic Fathers, pp. 760-61.

${ }^{90}$ See C.E. Hill, 'What Papias said about John (and Luke): A “New" Papian Fragment', JTS 49 (1998), pp. 582-629 (625-629), and the criticisms in Bauckham, Jesus and the Eyewitnesses, pp. 433-437.
} 
The question arises of Papias's date. ${ }^{91}$ According to Eusebius, he is a contemporary of Polycarp and Ignatius - he appears sandwiched between them (HE 3.36.1) ${ }^{92}$ and in another list he appears after Clement, Ignatius and Polycarp (3.39.1): the list PapiasPolycarp-Ignatius also appears in Jerome's version of Eusebius's Chronicon, placed at the end of the 219th Olympiad, i.e. around $100 \mathrm{CE} .^{93}$ Irenaeus is quoted as calling

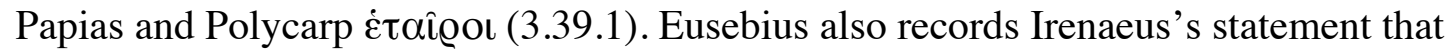

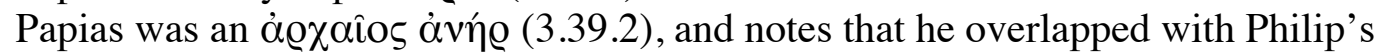
prophetic daughters (3.39.9) ${ }^{94}$ Eusebius disputes Irenaeus's claim that Papias was a hearer of John (3.39.1-2), and the passage he cites seems to support Eusebius's point. Even so, Aristion and John the elder managed to be both disciples of Jesus and contemporaries of Papias (3.39.4): in contrast to finding out from the elders what each

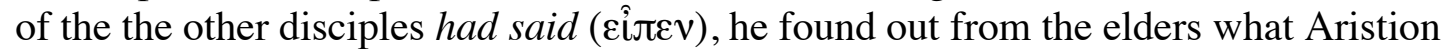

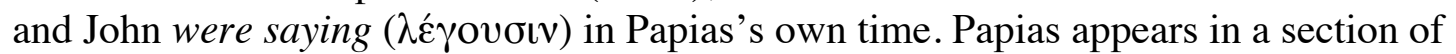
Eusebius (HE 3.32.1 to the end of book 3) devoted to the first dozen years of Trajan's principate (98-109 CE); book 4 begins in 'around the twelfth year' (109 CE). The natural conclusion from this is to place Papias's activity around 100, or very early in the second century, and his investigations may have taken place a decade or two earlier.

(xvi) Eusebius prefaces the quotation about Mark's authorship in EH 3.39.15 with the

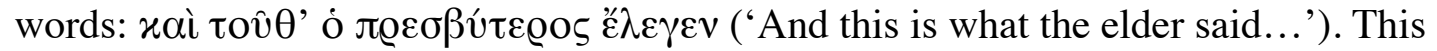
is evidently a reference to John the elder, noted in one of Eusebius's earlier fragments of Papias. It is clear that this John is noted as the source of the comments about Mark. What is less obvious is from where the remarks about Matthew come, because Papias begins in medias res with an oûv, and the same goes for Papias's statements about John's Gospel. It remains a possibility that both the Markan and the Matthean testimonia go all the way back to the elder. It may even be the most likely conclusion, given that Papias would presumably have wanted to get such information from someone in touch with the elder's 'living voice'. Notably, Papias writes that the elder

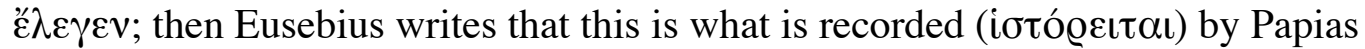

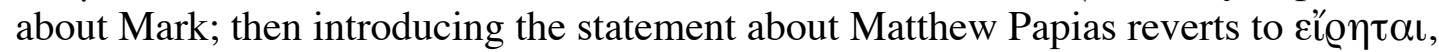
which may well imply the elder as the speaker again. In any case, John the elder pushes back the Markan testimonium back well into the first century.

Taken all in all, then, the first two centuries CE are populated by a good deal more references to Gospel authors than is commonly appreciated. The most common attestation is to John and Matthew in the top two, with Mark and Luke in the lower

\footnotetext{
${ }^{91}$ The best account here, with fairly devastating criticisms of a late date for Papias and compelling reasons for an early date, is that in R. Yarbrough, 'The Date of Papias: A Reassessment', JETS 26 (1983), pp. 181-191.

${ }^{92}$ Appended to this list later is Quadratus, who as we know from Eusebius's comment on his Apology, flourished in the time of Hadrian (EH 4.3.1-2).

${ }^{93}$ See Eusebius Werke VII/1. Hieronymi chronicon, ed. R. Helm (GCS; Leipzig: Hinrichs, 1913), pp. 193-194; see further on this Yarbrough, 'The Date of Papias', p. 186.

${ }^{94}$ Yarbrough notes further: 'The force of this appellation for Papias is strengthened when it is remembered that Irenaeus referred to John as seeing the Apocalypse "no very long time ago but almost in our own day, towards the end of Domitian's reign"' ('The Date of Papias', p. 187, referring to AH 5.30.3).
} 
tier, facts which roughly dovetail with the evidence from the papyri as well as with the relative frequency of biblical quotations from the period. ${ }^{95}$

\begin{tabular}{|l|l|c|c|c|c|}
\hline Date & Source & Matt. & Mark & Luke & John \\
\hline late ii-early iii & P66 & & & & \\
\hline late ii-early iii & P4 flyleaf & & & & $\checkmark$ \\
\hline c. 200 & Clement of Alexandria & $\checkmark$ & & & \\
\hline c. 200 & Act of Peter and the Twelve & $\checkmark$ & $\checkmark$ & $\checkmark$ & $\checkmark$ \\
\hline 190 s & Polycrates & & & & $\checkmark$ \\
\hline late ii & Muratorian Fragment & {$[\checkmark]$} & {$[\checkmark]$} & $\checkmark$ & $\checkmark$ \\
\hline $174-189$ & Irenaeus, Against Heresies & $\checkmark$ & $\checkmark$ & $\checkmark$ & $\checkmark$ \\
\hline c. 180 & Theophilus of Antioch & & & & $\checkmark$ \\
\hline c. $175-180$ & Hegesippus & & & & $\checkmark ?$ \\
\hline c. 175 & Apollinaris & $\checkmark$ & & & \\
\hline c. $150-200$ & Acts of John & & & & $\checkmark$ \\
\hline c. $150-175$ & Heracleon & & & & $\checkmark ?$ \\
\hline c. $150-175$ & Ptolemy & & & & $\checkmark$ \\
\hline c. $140-180$ & Gos. Thom. 13 & $\checkmark$ & & & \\
\hline c. $100 /$ early ii & Papias & $\checkmark$ & $\checkmark$ & & $\checkmark$ \\
\hline late i & (John) the Elder & & $\checkmark$ & & \\
\hline
\end{tabular}

\subsection{Two Significant Silences}

Two silences constitute important confirmation of a negative kind. First, there is never any sense among second-century authors that the Gospels are anonymous. Mention by second-century authors of 'the Gospel' tout simple does not imply anonymity or lack of knowledge of author. ${ }^{96}$ (I suspect that the frequent references to 'the Gospel' in the Apostolic Fathers have exercised undue influence here.) Talk of 'the Gospel' goes side by side with references to evangelists widely in second-century Christianity. Justin uses both the singular and the plural (as well as implying that he

\footnotetext{
${ }^{95}$ Hurtado lists the number of second-third century manuscripts for each Gospel as 'Matthew (12), Mark (1), Luke (7), John (16).' See L.W. Hurtado, The Earliest Christian Artifacts: Manuscripts and Christian Origins (Grand Rapids: Eerdmans, 2006), p. 20. The listing of patristic references to the Gospels in the first volume of Biblia Patristica, which essentially covers the second century, has for each of the evangelists: Matthew - c. 70 pages (pp. 223-293); Mark - c. 27 pages (pp. 293-319); Luke -c. 59 pages (pp. 319-378); John - c. 37 pages (pp. 379-415). See J. Allenbach et al. (eds.), Biblia Patristica: Index des citations et allusions bibliques dans la littérature patristique. I: Des origins à Clément d'Alexandrie (Paris: Éditions CNRS, 1975).

${ }^{96}$ Pace F.B. Watson, Gospel Writing: A Canonical Perspective (Grand Rapids: Eerdmans, 2013), p. 254, who assumes that at the time of 2 Clement "the term "Gospel" remains essentially anonymous and is not yet associated exclusively with the direct or indirect testimony of named apostles'. On the other side, see M. Hengel, Studies in the Gospel of Mark (London: SCM, 1985), p. 71.
} 
knows some attributions to the evangelists).$^{97}$ Irenaeus can also use the singular alongside the plural. ${ }^{98}$ Polycrates knows John as an evangelist, but also talks of 'keeping the passover on the fourteenth day, in accordance with the gospel, never deviating from it, but following the rule of faith' (Eusebius, EH 5.24.6), the gospel here not being a specific one. Theophilus talks about a particular evangelist writing, but elsewhere can refer simply, without reference to evangelists' names, to 'the Gospels' or (referring to the contents of Matthew) 'the Gospel voice' or 'the Gospel' (Autolyc. 3.12-14). The absence of any sense in the second century that the Gospels are anonymous means that Bauckham's contrast between Hebrews and John applies to all the Gospels. ${ }^{99}$ No one ever says, to mutilate Origen's famous remark about Hebrews, 'Who wrote the Gospels, only God knows!'100

The second silence is the absence of any other attributions of authorship assigned to the Gospels. (Even the idea that Gaius attributed the fourth Gospel to Cerinthus has been questioned; in any case, if it were true, such an attribution would be a clear parody of the conventional view. ${ }^{101}$ ) If the titles simply emerged very late, say in the mid- to late-second century, we would expect to find diversity among the names, but we do not. ${ }^{102}$

That a substantial time of anonymous transmission would probably lead to diversity of attributions can be illustrated by the case of Hebrews again. In Hebrews, which is clearly a letter (Heb. 13.24-25), the absence of the author's name really is striking. As a result, it seems that already in the second century, several suggestions of authorship had been made: Pantaenus had proposed Paul (Eusebius, EH 6.14.4), and a claim to Pauline authorship is also strongly suggested in $\mathfrak{P} 46$ (where Hebrews is sandwiched between Romans and 1 Corinthians); Tertullian states that Barnabas was the author, without any sense of an alternative view, citing the epistle as 'more widely accepted' than Hermas (Pud.2.1-5) in c. $210 \mathrm{CE}$; ${ }^{103}$ Origen, according to Eusebius, said that in addition to Paul, some attributed Hebrews to Clement of Rome and some to Luke the evangelist ( $E H$ 6.25.14) ${ }^{104}$ By around the beginning of the third century, then, no less than four different suggestions for the author of Hebrews had been made. This sort of diversity is exactly what we do not find in references to the authorship of the Gospels.

These two points are of course arguments from silence, but the silences are significance. They fit with the hypothesis that the names are attached to the Gospels very early, but sit uncomfortably with the line that the names are late. The later that one views the attributions to be, the harder these silences are to explain.

\footnotetext{
${ }^{97}$ Justin, Dial. 103.8 refers to composition by apostles and their followers: this distinction suggests that he knows particular apostles and followers. Justin also does not name Paul, whose writings he certainly knows.

${ }^{98}$ C.E. Hill, Who Chose the Gospels? Probing the Great Gospel Conspiracy (Oxford: Oxford University Press, 2010), pp. 179-180.

${ }^{99}$ Bauckham, 'Papias and Polycrates', p. 25.

${ }^{100} \mathrm{Cf}$. Origen apud Eusebius, EH 6.25.14.

${ }^{101}$ See n. 58 above.

${ }^{102}$ See e.g. Hengel, Four Gospels, p. 54.

${ }^{103}$ T.D. Barnes, Tertullian: A Historical and Literary Study (Oxford: Clarendon, 1971), p. 47.

${ }^{104}$ The homilies on Hebrews date to $c$. 239-242, according to P. Nautin, Origène: sa vie et son oeuvre (Paris: Beauchesne, 1977), p. 411.
} 


\section{Conclusion}

A good deal of the foregoing argumentation has been negative. This is because the first plank in the positive case for anonymity made by so many, viz. the absence of the author's name in the work, is completely insignificant ( $\$ 2)$. Even in the case of histories written in Greek, where the name is perhaps most frequently found in a preface in the work, there is by no means anything approach a rule to this effect. In consequence, it is a pointless exercise to try to give a theological rationale for why there is no self-reference.

The second plank in the case for anonymity is, as we have seen, the view that the present titles were only added later, with the often unstated implication that not only were the titles absent in their present form but that there were also no accompanying indications of authorship of any kind at all. The anonymity view not only has the (insufficiently acknowledged) difficulty of arguing for a negative here, it also has to contend with all the positive evidence against it. In addition to all the early references to the evangelists' names $(\$ 3.2)$, there is the difficulty of imagining Matthew and (perhaps especially) Luke accepting the second Gospel on trust without accompanying testimony ( $\$ 3.1)$, and also finally the important silences $(\S 3.3)$.

To follow up on the individual Gospels, we have noted that attribution of the second Gospel to Mark goes back to John the elder in the first century. This cannot be more than about 20 years after the composition of the Gospel. In light of this, it seems extremely unlikely that there was a time when Mark was not associated with the Gospel. The testimonia to Matthew are both early and scattered: Papias and the Gospel of Thomas are notable early witnesses. Again, there are only thirty-odd years between Matthew and Papias. Luke on the other hand is not attested as an author so early, in fact is not so before Irenaeus and the Muratorian fragment, whichever came first. However, of all the Gospels Luke is perhaps the least likely to be anonymous,

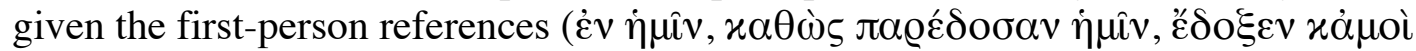

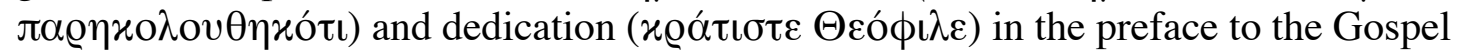

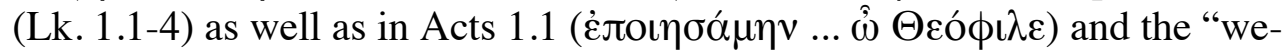
passages". John the evangelist has the greatest attestation of all the Gospels in the second century, across the theological spectrum from Valentinians to the Acts of John to the Acts of Peter and the Twelve, to Irenaeus, Theophilus and Polycrates, and reaching as far back in time as Papias. It is the purpose of this article to argue not that these figures actually wrote the Gospels, but that these names are probably original. In the light of these arguments, other hypotheses will have to be ventured besides anonymous publication. 